\title{
PENGGUNAAN MEDIA PEMBELAJARAN PLASTISIN UNTUK MENINGKATKAN KREATIVITAS ANAK USIA
}

\author{
THE USE OF PLASTISIN MEDIA \\ IN IMPROVING CHILDREN CREATIVITY
}

\author{
Kartini, Sujarwo \\ Pendidikan Luar Sekolah PPs UNY, Universitas Negeri Yogyakarta \\ kar.kamarudin88@gmail.com, sujarwo@uny.ac.id
}

\begin{abstract}
Abstrak
Penelitian ini bertujuan untuk mengetahui: (1) perbedaan kreativitas anak usia dini pada pembelajaran sebelum dan sesudah menggunaka media plastisin, (2) perbedaan kreativitas antara kelompok anak yang diajarkan dengan media plastisin dan media balok di TK Aisyiyah Bustanul Athfal 5 Mataram. Jenis penelitian yang digunakan adalah penelitian kuasi eksperimen dengan desain pretest-posttest control group design. Teknik observasi digunakan untuk mengetahui kreativitas anak. Teknik analisis data menggunakan uji T-test. Hasil penelitian menunjukan bahwa: (1) ada perbedaan kreativitas anak usia dini pada pembelajaran sebelum dan sesudah menggunakan media plastisin. (2) ada perbedaan yang signifikan mengenai kreativitas anak antara kelompok eksperimen dengan kelompok kontrol. Perolehan mean kreativitas eksperimen lebih besar dari pada mean kelompok kontrol yaitu 37,00 > 31,17. Hasil uji-t data posttest kemampuan kreativitas kelompok kontrol dan kelompok eksperimen menunjukkan bahwa nilai t-tabel dengan derajat bebas (df) 34 dengan taraf signifikansi $\alpha=0,05$ adalah sebesar 2,032. Nilai t- hitung 3,389 $>\mathrm{t}$-tabel 2,032 dan nilai $\mathrm{p}$-value $\mathrm{o}, 000<$ taraf signifikansi 0,05 .
\end{abstract}

Kata Kunci: penggunaan, media plastisin, kreativitas anak usia dini

\begin{abstract}
This research aims to know: (1) there are the differences of early childhood creativity of learning before and after using Plastisin, (2) the differences of creativity in learning by using Plastisin and Block of children group at TK Aisyiyah Bustanul Athfal 5 Mataram. This research used quasi-experiment with pretest-posttest control group design. The data collection technique used observation. Analysis data technique was done with T-test. The result of the research was (1) There are differences of early childhood creativities in learning before and after using plastisin media. (2) There are significance differences between creativities the experiment and control group. Creativity experiment mean was bigger than control group 37.00 $>31.17$. The result of $T$ test data from post-test, the creativity ablity of control and experiment group showed that $t$-table with standard deviation ( $\mathrm{df}$ ) 34 with significance $\alpha=0.05$ was 2.032. $t$-count score $3.389>t$-table 2.032 and p-value $0.000<$ significance 0.05 .
\end{abstract}

Keywords: the use of, plastisin media, children creativity. 


\section{PENDAHULUAN}

Pendidikan usia dini memegang peran yang sangat penting dalam perkembangan anak karena merupakan pondasi dasar dalam kepribadian anak. Dimana anak usia dini adalah generasi penerus bangsa di pundak merekalah kelak kita akan menyerahkan peradaban yang telah kita bangun dan akan kita tinggalkan. Anak berusia o-6 tahun memiliki masa perkembangan kecerdasan yang sangat pesat sehingga masa ini disebut golden age (masa emas). Masa ini merupakan masa dasar pertama dalam mengembangkan berbagai kegiatan dalam rangka pengembangan potensi, sikap, keterampilan, dan kreativitas pada anak usia dini. Undang-undang Nomor 20 Tahun 2003 tentang Sistem Pendidikan Nasional Pasal 1 ayat 14 dinyatakan bahwa pendidikan anak usia dini (PAUD) adalah suatu upaya pembinaan yang ditujukan kepada anak sejak lahir sampai dengan usia enam tahun yang dilakukan melalui pemberian rangsangan pendidikan untuk membantu pertumbuhan dan perkembangan jasmani dan rohani agar anak memiliki kesiapan dalam memasuki tahap pendidikan selanjutnya.

Pendidikan anak usia dini merupakan tempat belajar sekaligus bermain bagi anak. Anak diajarkan mengenal aturan, disiplin, tanggung jawab dan kemandirian dengan cara bermain. Anak juga diajarkan bagaimana mereka harus menyesuaikan diri dengan lingkungannya, berempati dengan temannya, tentunya juga berlatih bekerja sama dengan anak yang lain. Suyanto (200, p.114) menyatakan bahwa melalui kegiatan bermain yang mengandung edukasi, daya pikir anak terangsang untuk perkembangan emosi, sosial dan fisik. Setiap anak memiliki kemampuan dan ketertarikan bermain yang berbeda tergantung dari perkembangan anak. Dari permainan biasanya akan menimbulkan fantasi-fantasi besar oleh anak, dan tentu akan semakin menambah rasa ketertarikan anak pada mainan tersebut Montolalu (2008, p.1.19) mengatakan bahwa bermain bagi anak-anak mempunyai pengaruh yang sangat penting karena melalui bermain anak dapat menyalurkan segala kegiatan, kepuasan, kreativitas dan imajinasi- nya. Dengan demikian, anak dapat menjadi lebih kreatif melalui kegiatan bermain

Nugraha (2008, p.38). Mengatakan Pengembangan kreativitas pada anak prasekolah atau usia dini merupakan tujuan terpenting yang mesti diakomodasi kurikulum, karena anak yang kreatif akan mampu mengaplikasikan kemampuan kognitif, afektif dan psikomotornya secara lebih luas, melalui berbagai gagasan, untuk kemampuan atau keterampilan, produk benda/sesuatu atau bentuk pertanyaan-pertanyaan. Susan (2012, p.3) Creativity is theprocess of generating ideas that are novel and bringing into existence product that is appropriate and of high quality. Kreativitas merupakan proses memicu ide-ide dan merealisasikannya dalam bentuk produk nyata yang berkesesuaian dan memiliki kualitas yang tinggi.

Masa anak merupakan masa belajar yang potensial. Kurikulum untuk anak usia dini/TK harus benar-benar memenuhi kebutuhan anak dan sesuai dengan tahap perkembangan serta dirancang untuk membuat anak mengembangkan potensinya secara utuh. Kreativitas anak dimungkinkan akan tumbuh dan berkembang dengan baik apabila lingkungan keluarga, rumah maupun sekolah turut menunjang mereka dalam mengekspresikan kreativitasnya. Lingkungan memiliki pengaruh yang besar dalam perkembangan kreativitas anak. Kreativitas seorang anak tidak akan berkembang jika lingkungan tidak mendukung. Dalam era globalisasi ini, orang tua harus banyak melihat dan mengetahui bagaimana perkembangan anak, seperti perkembangan kreativitas anak. Semua orang tua mengingginkan anaknya menjadi anak yang berbakat dan kreatif. Akan tetapi mereka tidak tahu bagaimana sebenarnya merangsang kreativitas anak itu sendiri. Bahkan orangtua tidak mengetahui dan tidak mau tahu seperti apa ciri-ciri anak kreatif.

Berdasarkan observasi awal di Taman Kanak-Kanak ABA 5 Mataram kelas B sebelum penelitian, kegiatan pembelajarannya cenderung berupa pembelajaran yang "teacher centered" dimana anak dituntut untuk lebih menguasai kemampuan membaca, menulis dan berhitung (calistung). Guru 
cenderung berperan dominan dalam pembelajaran, guru mengarah anak untuk belajar sesuai dengan keinginannya dan lebih menyukai hasil anak sesuai dengan apa yang diperintahkannya sehingga anak tidak mempunyai kesempatan untuk memilih jenis kegiatan yang sesuai dengan minat anak. Hal tersebut akan mengakibatkan kreativitas anak tidak berkembang. Karena guru maupun orangtua masih beranggapan bahwa kreativitas anak sebagai hal yang bisa saja. Mereka lebih menekankan kemampuan anak dari segi akademik.

Dalam mengembangkan kreativitas anak perlu digunakan cara-cara tertentu agar kreativitas tersebut dapat berkembang dalam diri anak. Salah satunya yaitu dengan menerapkan permainan. Permainan adalah salah satu media pembelajaran yang dapat mengembangkan kreativitas, meningkatkan motivasi dan dapat mengurangi rasa bosan dan jenuh pada saat belajar.

Media pembelajaranpun memiliki peran yang penting dalam pengembangan kreativitas anak. Namun, sekarang ini media pembelajaran di Taman Kanak-Kanak yang dapat meningkatkan kreativitas anak masih kurang. Hal ini terlihat ketika guru memberikan sebuah kertas kosong dimana seluruh anak diminta untuk menggambar, sebagian besar anak tampak bingung, apa yang akan digambar di kertas tersebut. Seharusnya anak TK Kelompok B dengan usia 5- 6 tahun menurut menu pembelajaran anak usia dini, sudah mampu menciptakan berbagai desain/gambar (kurikulum Menu Generik, 2006). Selain itu, Media pembelajaran yang disediakan tidak menarik atau kurang efektif dimana media pembelajarannya hanya terpaku pada lembar kegiatan siswa (LKS) atau bersifat tekstual, sehingga proses pembelajaran terlihat monoton dan membuat anak cepat bosan untuk mengikuti proses pembelajaran. Oleh karena itu, perlu disediakan media yang dapat memfasilitasi perkembangan kreativitas anak yang disesuaikan dengan kebutuhan dan perkembangan anak. Permainan yang dapat mengembangkan kreativitas anak adalah media plastisin dan balok.

Swartz (2005, p.59) mengatakan bahwa plastisin merupakan bahan yang diguna- kan untuk bermain oleh anak-anak di kelas. Plastisin memberikan pengalaman yang menyenangkan dan memuaskan bagi anakanak, namun bukan hanya aktivitas "bersenang-senang". Melalui media ini, guru dapat menggunakan sebagai pembelajaran awal dan sebagai salah satu cara untuk mengobservasi perkembangan anak dalam berbagai area perkembangan. Ismail (2006, p.222) mengatakan bahwa media plastisin dapat melatih sekaligus mengembangkan kreativitas anak. Sebab, dengannya anak dapat melakukan aktivitas eksplorasi dalam membuat berbagai bentuk model secara bebas dan spontan Media plastisin merupakan bahan pokok untuk bermain anak usia dini selain itu, plastisin juga memberikan pengalaman yang menyenangkan dan memuaskan bagi anak. Kegiatan bermain plastisin ini dilakukan dengan cara membentuk, mewarnai dan mewarna sehingga menimbulkan bentuk. Media plastisin ini membuat anak suka berkreasi sehingga dapat mengembangkan kreativitasnya. Anak dilatih untuk menggunakan imajinasi untuk membuat atau menciptakan suatu bangunan atau benda sesuai dengan khayalannya seperti angka, abjad, binatang dan lain-lain.

Mulyadi (2004, p.59) menjelaskan bermain balok adalah jenis kegiatan yang sifatnya konstruktif, dimana anak mampu membangun sesuatu dengan menggunakan balok-balok yang sudah disediakan. Hal ini senada dengan pendapat Segal (2012, p.185) yang menyatakan bahwa:

That building with blocks, toddlers enjoy creating and experimenting with blocks. They are learning how to carry blocks, line up blocks, stack blocks, balance bigger blocks on smaller blocks, and nest blocks in unique. Provide block of different sizes, shapes, and textures as well as cardboard blocks, nesting blocks, plastic blocks, and small unit blocks. Also provide block that snap or stick together easily and can be used to create a variety of buildings, vechicles, furniture, or designs.

Segal menyatakan bahwa kegiatan menyusun balok, anak dapat menikmati menciptakan dan mengadakan percobaan dengan media balok. Mereka belajar tentang 
bagaimana membariskan balok, menumpukkan balok, menyeimbangkan balok yang lebih kecil ke atas balok yang lebih besar dan menyusun balok dengan cara yang unik. Penyediaan balok dengan berbagai ukuran, bentuk, tekstur yang berbeda maupun pengumpulan kardus balok, balok plastik, dan unit balok yang kecil-kecil serta penyediaan balok yang berbentuk kotak atau batangan dengan secara bersama-sama memudahkan dan bisa digunakan untuk menciptakan susunan bangunan yang bervariasi, wahana, prabotan atau rancangan.

Pengembangan kreativitas anak sangat perlu dikembangkan kepada anak sejak dini agar anak matang ketika memasuki usia sekolah. Anak siap menghadapi permasalahan yang muncul. Setiap media permainan dapat difungsikan secara multiguna dan memiliki kekhususan untuk mengembangkan aspek perkembangan pada anak, selain itu balok juga dapat dimainkan dengan berbagai cara dan bentuk untuk melatih tidaknya motorik halus tetapi juga mengenal konsep warna, ukuran, dan bentuk pada anak sehingga muncul kreativitas anak. Seperti halnya balok, media plastisin juga dapat melatih daya pikir anak. Anak dapat mengeksplorasi dan mencari informasi tentang segala sesuatu yang belum mereka ketahui. Ismail (2006, p.222) menyatakan bahwa plastisin dapat melatih sekaligus mengembangkan kreativitas anak. Sebab, dengannya anak dapat melakukan aktivitas eksplorasi dalam membuat berbagai bentuk model secara bebas dan spontan. Bermain dengan plastisin, anak-anak dapat mengekspresikan kreativitas mereka dengan menemukan serta membuat gaya-gaya unik dari cara berekspresi masing-masing. Setiap hasil karya bermain dengan plastisin akan berbeda dari satu anak dan lainnya, sama halnya dengan perbedaan dalam penampilan maupun kepribadiannya masing-masing anak. Manfaat bermain menggunakan media plastisin anak dapat mengkoordinasikan jari-jari tangan, melenturkan otot-otot jari tangan, melatih keuletan dan kesabaran serta mengembangkan imajinasi dan kreativitas anak.

Berdasarkan latar belakang tertsebut maka peneliti mengambil judul penelitian "Penggunaan Media Pembelajaran Plastisin
Untuk Meningkatkan Kreativitas Anak Usia Dini (Sebuah Penelitian Eksperimen Kuasi di TK Aisyiyah Bustanul Athfal 5 Mataram Kelompok B Tahun Ajaran 2013/2014)".

Penelitian ini bertujuan untuk mengetahui perbedaan kreativitas anak usia dini pada pembelajaran sebelum dan sesudah menggunakan media plastisin di kelompok B TK Aisyiyah Bustanul Athfal 5 Mataram, perbedaan kreativitas anak usia dini pada pembelajaran sebelum dan sesudah menggunakan media balok di kelompok B TK Aisyiyah Bustanul Athfal 5 Mataram, perbedaan kreativitas antara kelompok anak yang diajar dengan media plastisin dan media balok di TK Aisyiyah Bustanul Athfal 5 Mataram.

Berdasarkan tujuan penelitian yang hendak dicapai maka penelitian ini diharapkan mempunyai manfaat dalam pendidikan baik secara langsung maupun tidak langsung. Adapun manfaat secara teoritis hasil penelitian ini diharpkan dapat memberikan sumbangan pemikiran bagi akademik dapat memberikan informasi dan kajian tentang belajar dengan media permainan plastisin dan balok dalam meningkatkan kreativitas anak usia dini di taman kanak-kanak, dan memberikan sumbangan ilmu pengetahuan yang bermanfaat terutama dalam pengembangan kreativitas anak usia dini yang diperoleh melalui kegiatan bermain dengan belajar yang menyenangkan.

Kajian penelitian yang relevan dengan penelitian oleh Zahrah Universitas Alkhairaat: (2011) tentang Penerapan Belajar Melalui Bermain dalam Meningkatkan Kreativitas dan Motorik Halus Anak Usia Dini pada TK Alkhairaat I Pusat di Kota Palu menunjukkan bahwa penerapan pembelajaran melalui bermain balok unit secara signifikan berpengaruh terhadap peningkatan kreativitas dan motorik halus anak sedangkan pada pendekatan konvensional tidak berpengaruh terhadap peningkatan kreativitas anak usia dini pada TK Alkhairat. Belajar melalui balok unit dapat meningkatkan kreativitas dan motorik halus anak usia dini. 


\section{METODE}

Penelitian ini menggunakan jenis penelitian quasi eksperimental atau eksperimen semu, karena penelitian ini dilakukan dengan maksud untuk melihat pengarus dari suatu perlakuan. Tuckman (1972, p.113) mengatakan bahwa penelitian kuasi eksperimen seperti halnya penelitian murni namun subjek penelitian tidak dipilih secara acak. Kirk (1995, p.6) bahwa penelitian kuasi eksperimen didasarkan atas alasan praktis dan etis (etika). Penelitian ini menggunakan pendekatan kuantitatif karena dalam penelitian ini untk menguji hipotesis yang telah ditetapkan menggunakan analisis statistik dalam mengolah data Sugiyono (2010, p.14).

\section{Jenis Penelitian}

Penelitian ini menggunakan jenis desain pretest-posttest control group desig. Dalam disain ini kelompok eksperimen maupun kelompok kontrol tidak dipilih secara random, sebelum diberikan, kelompok diberikan Pretest dengan maksud untuk mengetahui keadaan awal apakah ada perbedaan antara kelompok kontrol. Hasil pretest yang baik bila nilai kelompok eksperimen tidak berbeda secara signifikan. Desain ini dapat digambarkan sebagai berikut:

Tabel 1

\begin{tabular}{cccc}
\hline Group & Pretest & Treatmen & Posttest \\
\hline $\mathrm{A}$ & $\mathrm{O}_{1}$ & $\mathrm{X}_{1}$ & $\mathrm{O}_{2}$ \\
B & $\mathrm{O}_{3}$ & $\mathrm{X}_{2}$ & $\mathrm{O}_{4}$ \\
\hline
\end{tabular}

Sugiyono (2012, p.112)

Keterangan:

A = Eksperimen Group

$\mathrm{B}=$ Kontrol Group

$\mathrm{O}_{1}=$ Pretest sebelum diberi perlakuan pada kelompok ekperimen

$\mathrm{O}_{2}=$ Posttest setelah diberi perlakuan pada kelompok eksperimen

$\mathrm{X}_{1}=$ Perlakuan media pembelajaran plastisin.

$\mathrm{X}_{2}=$ Perlakuan media pembelajaran balok.

$\mathrm{O}_{3}=$ Pretest pada kelompok kontrol

$\mathrm{O}_{4}=$ Posttest pada kelompok kontrol

\section{Waktu dan Tempat}

Penelitian ini dilakukan pada bulan Februari sampai April 2014, bertempat di TK
Aisyiyah Bustanul Athfal 5 Mataram kelompok B.

\section{Populasi dan Sampel}

\section{Populasi}

Populasi dalam penelitian ini adalah seluruh peserta didik TK Aisyiyah Bustanul Athfal 5 Mataram yang ada di kelas B yang tesebar dalam 3 kelas dengan jumlah anak secara keseluruhan 54 anak. Dalam penelitian dipilih kelompok B karena anak-anak pada kelompok ini berusia 4-5 tahun yang sedang berkembang kreativitasnya, sehingga penelitian ini diharapkan dapat bermanfaat bagi perkembangan peserta didik selanjutnya

\section{Sampel}

Pengambilan sampel dalam penelitian ini dilakukan dengan menggunakan teknik Cluster Sampling. Penentuan kelompok eksperimen dan kontrol dilakukan secara acak dengan teknik undian, maka diperoleh kelompok B1 sebagai kelompok eksperimen dan kelompok B2 sebagai kelompok kontrol.

\section{Prosedur}

\section{Tahap Persiapan}

Memilih dua kelas dari subjek penelitian yang ada untuk dijadikan tempat penelitian. Pemilahan tersebut dilakukan secara acak. Subjek yang dipilih yaitu kelas Bı sebagai kelompok eksperimen dan kelas $\mathrm{B}_{2}$ sebagai kelompok kontrol. Kemudian menyiapkan rancangan kegiatan Mingguan (RKM) dan Rancangan kegiatan harian (RKH) kedua kelompok yaitu kelompok yang diajarkan dengan media pembelajaran plastisin dengan media pembelajaran balok. Memberikan pengarahan kepada guru tentang pembelajaran dengan menggunakan media plastisin dan balok untuk meningkatkan kreativitas anak usia dini. Melakukan kesepakatan bahwa pembelajaran dilakukan oleh guru, peneliti hanya sebagai observasi dan patner guru. selain itu kegiatan pembelajaran dilakukan sesuai dengan jadwal yang telah direncanakan dan memvalidasi instrumen penelitian dari segi empiris untuk memperoleh instrumen penelitian yang valid dan reliabel. 
Tahap Pelaksanaan

Pelaksanaan dalam eksperimen ini, terlebih dahulu dilakukan pretest untuk kelompok perlakuan dan kelompok kontrol. Selanjutnya untuk kelompok eksperimen diberikan perlakuan menggunakan media pembelajaran plastisin, sedangkan pada kelompok control tidak diberikan media pembelajaran plastisin tetapi mengunakan media pembelajaran yang lain yaitu media pembelajaran balok. Setelah perlakuan media pembelajaran plastisin diberikan, peneliti kembali melakukan post-testkepada subjek penelitian.

Tahap Kegitan Akhir

Tahap kegiatan akhir yaitu melakukan analisis data hasil pretest, posttest pedoman lembar observasi dan penulisan laporan.

\section{Teknik dan Instrument Pengumpulan Data}

Data dalam penelitian bersumber dari anak didik dalam pembelajaran yang berupa perlakuan belajar yang dihasilkan anak. data yang diambil disini adalah data tentang kreativitas anak usia dini. Pengambilan data pada penelitian ini dilakukan dengan observasi dan dokumentasi.

Pengumpulan data melalui observasi yaitu bentuk pengamatan yang dilakukan secara langsung ke objek yang berjumlah 36 responden penlitian, yang terdiri dari 18 objek kelompok plastisin, dan 18 responden kelompok balok. Pretest dilakukan dengan mengamati kreativitas anak. Pretest dimaksudkan untuk mengetahui anak sebelum perlakuan media plastisin. Dalam pelaksanaan pretest, penelitian dibantu oleh 2 observer yaitu guru kelas Taman Kanak-kanak Aisyiyah Bustanul Athfal (ABA) 5 Mataram. Observasi yang dilakukan meliputi observasi tentang proses peningkatan kreativitas anak setelah menggunakan media pembelajaran plastisin dan balok. Dalam melakukan observasi ini, peneliti berpedoman pada lembar observasi.

Dokumentasi digunakan untuk memperoleh data sekolah dan nama siswa kelompok B TK ABA 5 Mataram. Dokumentasi juga berupa foto proses kegiatan terhadap perlakuan penelitian, yaitu kegiatan proses pembelajaran melalui media plastisin dan balok.

\section{Teknik Analisis Data}

Analisi data dalam penelitian ini menggunakan teknik analisis data uji-t. Penggunaan uji-t dimaksudkan untuk menguji perbedaan mengenai kreativitas anak yang diajarkan menggunakan media pembelajaran plastisin dengan kelompok kontrol melalui media pembelajaran balok. penghitungan seluruh analisis data dilakukan dengan menggunakan aplikasi SPSS 16.o.

\section{HASIL DAN PEMBAHASAN}

\section{Hipotesis 1}

Berdasarkan Uji hipotesis yang pertama penelitian ini adalah "ada perbedaan kreativitas anak usia dini pada pembelajaran sebelum dan sesudah menggunakan media plastisin". Berdasarkan hasil pretest dan posttest pada media pembelajaran plastisin diketahui perbedaan hasilnya yaitu 37,00 > 29,11 dengan nilai $t_{\text {-hitung }}$ sebesar 7,119 dan nilai $p$-value (sig) sebesar o,ooo. Nilai t-tabel dengan derajat bebas (df) 34 taraf signifikansi $\alpha=0,05$ adalah sebesar 2,032. Nilai thitung 7,119> t-tabel 2,032 dan nilai $p$-value $0,000<$ taraf nyata 0,05 . Hal ini menandakan bahwa ada perbedaan yang signifikansi. Oleh karena itu, hipotesis $\mathrm{H}_{\mathrm{o}}$ ditolak dan $\mathrm{H}_{1}$ diterima, sehingga $\mathrm{H}_{1}: \mu 1 \neq \mu 2$ yang berarti ada perbedaan yang signifikan mengenai kreativitas anak antara kelompok anak yang diajarkan sebelum dan sesudah menggunakan media pembelajaran plastisin.

Hasil analisis data penelitian tersebut membuktikan adanya perbedaan yang signifikan mengenai kreativitas anak sebelum dan sesudah menggunakan media plastisin. Penggunaan media plastisin terbukti lebih mampu untuk meningkatkan kreativitas anak usia 4-5 tahun. Hal ini terlihat bahwa ketika mengerjakan kegiatan keterampilan yang diberikan masih banyak terlihat anak yang hanya mencontek kegiatan temantemannya dan anak tidak berani menambahkan bentuk lain dari contoh yang sudah ada, anak didik banyak yang mulai bosan 
dengan kegiatan tersebut, sehingga banyak anak yang lebih memilih ngobrol dengan temannya ketika mengerjakan keterampilan menjiplak, menggambar dan menggunting, disini terlihat kurangnya kreativitas anak yang muncul dikarenakan proses pembelajaran yang mononton. Namun setelah diberikan media pembelajaran plastisin kreativiitas anak mulai meningkat, hal ini disebabkan karena, ketika proses pembelajaran berlangsung anak-anak sangat antusias dan kelihatan anak-anak senang ketika menggunakan media plastisin sebagai alat pembelajarannya, hal tersebut terlihat pada kegiatan mereka disaat meremas, memukulmukul dan mencabik-cabik sampai membentuk media plastisin yang sesuai dengan yang diinginkannya.

Penggunaan media plastisisn merupakan salah satu alat permainan yang dapat mendorong imajinasi anak. karena melalui media plastisin ini akan membuat anak suka berkreasi sehingga dapat mengembangkan kretaivitasnya. Hal ni sesuai dengan pendapat Ismail (2006, p.222) yang menyatakan bahwa media plastisin dapat mengembangkan kreativitas anak, sebab anak dapat melakukan aktifitas eksplorasi dalam membuat berbagai bentuk model secara bebas dan spontan. Selain dapat meningkatkan kreativitas anak media plastisin juga bermanfaat untuk membantu pengenalan warna, melenturkan otot-otot jari dan tangan. Pemanfaatan media plastisin, selain dapat menigkatkan kreativitas, anak juga dapat mendukung peningkatan kemampuan motorik halus dan motorik kasar.

Pembelajaran melalui permainan media plastisin ini adalah sebuah permainan yang dirancang khusus untuk meningkatkan kreativitas dan mengembangkan kemampuan motorik halus anak yang berusia 5-6 tahun. Berdasarkan hasil penelitian ini maka dapat dibuktikan bahwa media plastisin memiliki perbedaan yang signifikan terhadap kreativitas anak usia dini.

\section{Hipotesis 2}

Uji hipotesis yang kedua penelitian ini adalah "ada perbedaan yang signifikan mengenai kreativitas antara kelompok anak yang diajarkan menggunakan media pem- belajaran plastisin dengan media pembelajaran tanpa menggunakan media plastisin namun melalui media pembelajaran balok. Berdasarkan hasil mean kreativitas kelompok eksperimen yaitu anak yang diajarkan dengan media plastisin dan kelompok kontrol yaitu anak yang mendapatkan media pembelajaran balok diketahu perbedaan hasilnya yaitu 37,00 > 31, 17. Berdasarkan analisis perhitungan uji-t diperoleh nilai thitung sebesar 3,389 dan nilai p-value (sig) sebesar 0.002 sedangkan nilai $t_{- \text {tabel }}$ dengan derajat bebas (df) 34 taraf signifikansi $\alpha=$ 0,05 adalah sebesar 2,032. Dengan demikian

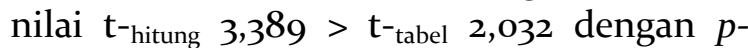
value $0,002<$ taraf nyata 0,05 . Maka hipotesis $\mathrm{H}_{\mathrm{o}}$ ditolak dan $\mathrm{H}_{1}$ diterima, sehingga $H_{1}: \mu_{1} \neq \mu_{2}$ hal ini menandakan bahwa ada perbedaan yang signifikan antara anak yang diajarkan dengan mengunakan media plastisin dan kelompok kontrol yaitu anak yang diajarkan menggunakan media pembelajaran balok.

Hasil analisis tersebut menbuktikan adanya perbedaan yang signifikan mengenai kreativitas anak antara kelompok yang diajar menggunakan media pembelajaran plastisin dengan kelompok anak yang diajar menggunakan media pembelajaran balok, atau dengan kata lain media pembelajaran plastisin lebih efektif untuk meningkatkan kreativitas pada anak usia dini.

Berdasarkan uraian pembahasan di atas, perlakuan diberikan kepada kelompok eksperimen dengan pembelajaran media plastisin dan kelompok kontrol dengan pembelajaran balok. Pada proses pembelajaran yang diterapkan berpusat pada peserta didik dan bukan pada pendidik namun pada pendidik hanya memberikan penerapan-penerapan cara mengembangkan kreativitas anak melalui media-media permainan khususnya pada media plastisin dan balok. Oleh karena itu, diperlukan berbagai macam untuk mewujudkan proses pembelajaran yang memberikan kesempatan kepada peserta didik untuk mengembangkan potensi kreativitasnya. Maka dari itu, salah satu usaha untuk mencapai tujuan tersebut adalah dengan melakukan dan menerapkan suatu media pembelajaran khususnya melalui media balok dan plastisin. Melalaui 
penggunaan media balok merupakan salah satu cara memberikan kesempatan berkembangnya kreativitas, melatih keterampilan motorik halusnya, karena melalaui permainan media balok anak dapat menciptakan berbagai macam benda seperti membuat rumah, kereta api, kolam ikan, trowongan dan masih banyak lagi yang lainnya. Dimayanti (2008, p.24) menyatakan bahwa salah satu manfaat dari pembelajaran menggunakan media balok yaitu anak dapat meningkatkan motorik kasar, motorik halus serta kreativitas. Selain itu, anak juga dapat mengenal konsep matematika yaitu dapat mengenal konsep berat, ringan, panjang, pendek, besar, kecil, tinggi, rendah, dan mampu mengkelompokkan benda berdasarkan bentuk dan warna.

Namun pada saat kegiatan media balok di TK ABA 5 Mataram, anak aktif namun tidak semua anak ikut mengerjakan tugas keterampilan seperti menyusun sebuah bangunan hingga membentuk rumah, gedung, waduk, menara dan lain-lain. Selain itu, media balok yang diberikan pada setiap anak hanya 50 buah sehingga tidak sesuai dengan konsep yang sudah ditentukan yaitu dalam permainan balok setiap anak mendapatkan 100 buah balok, namun hal tersebut tidak diterapkan, kurangnya kebebasan pada anak untuk memilih balok-balok yang akan digunakan dalam kegiatan permainannya, disebabkan guru kurang profesional alasannya para guru kurang bersedia untuk menata balok-balok tersebut pada tempat yang sudah di tentukan.

Ketika bermain plastisin, anak merasa bebas untuk membuat berbagai bentuk yang ia suka. Sehingga tidak terlihat adanya pengaruh bermain plastisin terhadap kreatifitas anak. Berdasarkan hasil penelitian, juga dapat dilihat bahwa nilai kreativitas individu lebih rendah jika dibandingkan kelompok anak yang diajarkan dengan menggunakan media pembelajaran balok. Hal ini karena anak yang bermain secara individu masih lebih berfokus pada plastisinnya masing-masing. Tidak adanya diskusi dengan teman, membuat mereka lebih memusatkan perhatian pada plastisin dan imajinasinya sendiri. Hal ini sesuai dengan penelitian yang dilakukan oleh Lloyd \& Howe (2003) bahwa anak prasekolah yang bermain secara individu cenderung pasif, memiliki korelasi negatif dengan kreativitasnya. Selama observasi pada anak yang bermain secara individu, peneliti melihat sebagian besar anak selalu mengubah bentuk plastisin yang telah mereka buat. Jika pada awalnya mereka telah membuat suatu bentuk hingga jadi, namun karena kurang puas dengan bentuk yang telah dibuat, mereka meremas bentuk tersebut hingga hanya menjadi sebuah bulatan. Bulatan plastisin tersebut kemudian dibentuk ulang menjadi bentuk baru yang berbeda dengan bentuk sebelumnya. Sebagian besar anak melakukan hal tersebut lebih dari 2 kali. anak tidak memiliki tujuan yang pasti sejak awal akan membuat bentuk apa, sehingga mereka sering mengubah bentuk plastisin yang telah jadi. Hal ini diperkuat dengan hasil penelitian Lloyd \& Howe (2003) bahwa anak-anak tidak menggunakan waktu bermain secara individu mereka untuk kegiatan yang memiliki tujuan yang pasti.

Media pembelajaran memiliki peran yang penting dalam pengembangan kretivitas anak. Kegiatan pembelajaran itu harus dibuat menyenangkan, menarik perhatian anak dan membuat anak nyaman agar proses pembelajaran dapat berlangsung lebih efektif. Seperti yang dikemukakan oleh Miarso (2007, p.458) bahwa media pembelajaran merupakan alat yang digunakan untuk menyalurkan pesan serta dapat merangsang pikiran, perasaan, perhatian sehingga kemauan anak dalam belajar dapat terdorong untuk menciptakan proses pembelajaran yang bertujuan dan terkendali. Karena melalui media merupakan salah satu metode yang dapat memberikan kesenangan pada anak dan membantu anak kreatif.

Untuk mewujudkan bakat kreativitas seorang anak, diperlukan dorongan melalui media pembelajaran yaitu media pembelajaran plastisin yang merupakan salah satu media yang disenangi oleh anak-anak serta dapat meningkatkan kreativitas yang dimiliki oleh anak. Penggunaan media pembelajaran plastisin terbukti lebih mampu untuk menigkatkan kreativitas anak usia 4-5 tahun. Penggunaan media plastisin merupakan salah satu alat permainan yang dapat 
mendorong imajinasi anak. Karena melalu media palstisin ini akan membuat anak suka berkreasi sehingga dapat mengembangkan kreativitasnya.

Berdasarkan penelitian Howard-Jones: (2002) yang dilakukan pada 52 anak usia 6 tahun. Sebagian anak diberikan plastisin kemudian dibiarkan untuk bermain plastisin selama 25 menit. Hasilnya menunjukkan bahwa anak yang bermain plastisin memiliki nilai kreativitas yang lebih tinggi jika dibandingkan anak yang tidak bermain plastisin. Hal ini juga sama seperti penelitian yang dilakukan oleh Rochayah (2012) yang menemukan bahwa terdapat peningkatan kreativitas anak TK yang bermain plastisin. Media pembelajaran plastisin menjadi sebuah media pembelajaran yang dapat memberikan sumbangsihnya sebagai media pembelajaran yang membantu dalam pembelajaran dengan tujuan kreativitas.

Berdasarkan hasil penelitian maka dapat dibuktikan bahwa anatar media pembelajaran plastisin dengan media pembelajaran balok memiliki perbedaan yang signifikan untuk meningkatkan kreativitas anak usia dini. Oleh karena itu, penggunaan media pembelajaran plastisin dapat dijadikan pilihan utama dalam meningkatkan kreativitas anak usia dini.

\section{PENUTUP}

\section{Simpulan}

Berdasarkan pembahasan pada babbab sebelumnya, maka dapat ditarik kesimpulan bahwa ada perbedaan yang signifikan mengenai kreativitas anak usia dini antara kelompok anak yang diajarkan menggunakan media pembelajaran plastisin dengan kelompok kontrol yang menggunakan media balok di TK ABA 5 Mataram. Hal ini terbukti pada perolehan mean kreativitas kelompok eksperimen lebih besar dari pada kelompok kontrol yaitu 37,00 > 31,17 dengan

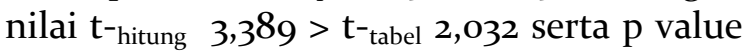
$0,002<$ taraf nyata 0,05 .

\section{Saran}

Bagi para pendidik TK ABA 5 Mataram, mengingat bahwa media pembelajaran memiliki kontribusi dalam meningkatkan kreativitas perkembangan kecerdasan anak usia dini (prasekolah), maka guru diharapkan menggunakan media pembelajaran plastisin dan balok secara berkelanjutan untuk mengembangkan kreativitas anak usia dini agar pencapaian perkembangan anak terus meningkat. Bagi para pendidik penelitian ini dapat dijadikan sebagai bahan refleksi bahwa pembelajaran dengan menggunakan media plastisin dan balok yang semula ditanggapi dengan keragu-raguan dan kecemasan telah menghasilkan hasil yang optimal, yaitu pola berfikir dan imajinasi anak semakin berkembang. Melalui penelitian ini bisa meyakinkan para guru untuk meneruskan media pembelajaran ini sebagai salah satu media pembelajaran yang digunakan di sekolah. Para pendidik juga harus lebih proaktif dengan menambah warna mencari informasi baru tentang media pembelajaran APE lain serta cara mengembangkan kreativitasnya.

Bagi pengembang, perencanaan, penyelenggaraan dan pelaksana pendidikan. Hasil penelitian ini dapat dijadikan sebagai masukan dalam pengembangan, perencanaan dan penyelenggaraan program pendidikan anak usia dini. Secara khusus, penelitian ini mampu memberikan sumbangan pemikiran bagi pengembangan pembelajaran anak usia dini dengan memanfaatkan media pembelajaran APE dalam kegiatan bermain sambil belajar ternyata dapat mengembangkan kreativitas anak usia dini.

Bagi orang tua hendaknya dapat menindak lanjutkan media pembelajaran APE ini di rumah. Media pembelajaran balok dan plastisin ini dapat dijadikan sebagai masukan dalam melaksanakan perannya di rumah sehingga dapat mencapai hasil yang optimal sesuai dengan tujuan yang telah ditetapkan pada pendidikan PAUD.

Bagi penelitian selanjutnya diharapkan di dalam proses pemberian suatu perlakuan dilakukan dalam kurun waktu yang lebih lama, secara berkelanjutan dan di seluruh tingkatan usia. Media pembelajaran balok dan plastisin sangat kompleks, masih banyak yang dapat diteliti dan dianalisa untuk masing-masing aspek, serta pola pembelajarannya. Karena keterbatasan waktu dan kemampuan peneliti, penelitian ini 
hanya dapat menjaring 15 butir item kreativitas. Penelitian selanjutnya diharapkan dapat mengangkat kembali permasalahan yang ada tetapi dengan metode, teknik, strategi, dan media yang lain serta tindakan yang berbeda agar dapat memberikan masukan atau temuan-temuan baru khususnya dalam meningkatkan kreativitas anak sehingga dapat mengembangkan potensi anak secara optimal.

\section{DAFTAR PUSTAKA}

Howard-Jones, P.A., Taylor, J., \& Sutton, L. (2002). The effect of play on the creativity of young children during subsequent activity. Journal Early Child Development and Care. 323328.

Ismail, A. (2006). Education games menjadi cerdas dan ceria dengan permainan edukatif. Yogyakarta: Pilar Media.

Kirk, R.E. (1993). Exsperimental design: procedure for the behavioral sciences. California. Broks Cole Publishing Company.

Lloyd, B. \& Howe, N. (2003). Solitary play and convergent and divergent thinking skills in. Preschool Children. Journal Early Childhood Research Quarterly, 18, 22-41.

Miarso, Yusufhadi. (2007). Menyamai benih teknologi pendidikan. Jakarta: Kencana.
Mulyadi. (2004). Kreativitas dan bermain. Disertasi, Jakarta: Universitas Indonesia. Tidak diterbitkan.

Montolalu, dkk. (2008). Bermain dan permainan Anak. Jakarta: Universitas Terbuka.

Nugraha, A, dkk. (2008). Materi pokok kurikulum $\mathcal{E}$ bahan belajar TK. Jakarta: Universitas Terbuka.

Sugiyono, (2010). Metode penelitian pendidikan pendekatan kuantitatif, kualitatif, dan REDD. Bandung: Alfabeta.

Sugiyono, (2012). Metode penelitian kuantitatif kualitatif dan RED. Bandung: Alfabeta

Susan, W. (2012). Understanding creativity early Childhood; London. Sage.

Suyanto, S. (2005). Dasar-Dasar Pendidikan anak usia dini. Yogyakarta: Hikayat.

Swartz, M.I. (2005). Playdough: what's standard. young children. New Youk: Mc Graw Hill.

Tuckman, B.W. (1972). Conducting education researc. New York: Harcourt Brace Jovanovich, Inc.

Zahrah (2011) Penerapan belajar melalui bermain dalam meningkatkan kreativitas dan motorik halus anak usia dini. Skripsi, tidak dipublikasikan. Universitas Alkhairat. 